\title{
COMMENT
}

\section{OPERATION OF BUSINESSES BY TRUSTEES}

Common law trust principles impose a duty of conservative prudence upon trustees administering the estates of decedents. This comment analyzes these traditional rules in terms of whether they provide realistic and workable standards when applied to trustees who are charged with the continuation of a decedent's business.

RECENT XEARS have evidenced an increasing interest in the use of the trust device ${ }^{1}$ to continue going businesses. ${ }^{2}$ This development is attributable to several factors. There are more commercial enterprises in the United States today than at any other time in history. ${ }^{3}$ Experience indicates that the bargaining position of a retiring owner or of an executor attempting to sell a business is weak.4 Thus, apart

\footnotetext{
1 "[W]e are seeing a day in which the properties left behind by the heads of American families are less likely, to be balanced portfolios of capital assets and are more likely to be going businesses. The problem of modern trusteeship ... is therefore likely to be not so much one of safe conservation of assets . . . as it is one of alert and successful management of going businesses." Shattuck, The Art of Estate Planning, 87 Trusts \&: Estates 13 (1948).

Since Mr. Shattuck's statement, the contents of professional journals bear out his prediction. See, e.g., Barclay, Continuing Business in Estates, 102 Trusts \& EsTates 138 (1963); Cowdery, When a Trustee Has a Business to Handle, Trust Bull., June 1958, p. 14; Durand, Changing Concepts of Trust Investments, 95 Trusts \& EsTates 907 (1956); Foulke, The Family Business: How Special Division of Trust Department Handles Closely Held Firms, 100 Trusts \& EsTates 606 (1961); Golden, Perpetuating Family Business Through Estate Planning, 99 Trusts \& Estates 906 (1960); Handling Businesses in Trust, 93 Trusts \& Estates 105 (1954); Palmer, Handling Problems of the Close Corporation, 101 Trusts \& Estates 1046 (1962); Pope, When Trustee Goes in Business, 91 TRUSTs \& EsTaTEs 8 (1952); Stratford, Handling Businesses in Trust, Trust Bull., Dec. 1957, p. 38; Wilking, Trustee's Compensation for Handling Businesses in Trust, 99 Trust \& Estates 12 (1960); Willcox, Blueprint for Handling Business Interests, 98 TRUSTS \& EsTates 662 (1959).

Most of the trust business and litigation conceruing trustee-held businesses has arisen in the context of testamentary trusts. "Thus, unless it is stated to be otherwise, "settlor" may in this comment be read as synonymous with "testator."

2 Only a settlor's sole proprietorship or interest in a corporation will be considered in this comment. Treatment of partnership interests is omitted because the opportunity for the trustee's active participation in the affairs of the business is completely governed by the acquiescence of the surviving partner or partners. See Crane, Partinershry $\$ 90 \mathrm{a}$ (2d ed. 1952); Fuller, Partnership Agreements for Continuation of an Enterprise After the Death of a Partner, 50 YALE L.J. 202, 209-10 (1940).

'See U.S. DeP't of Commerce, Statistical Abstract 490 (1965).

The basic problems lie in valuing the business. The owner of a sole proprietorship may have difficulty in selling his business for what he feels is its real value, since
} 
from tax considerations, ${ }^{5}$ resort to the trust device allows a settlor

much of this value may be in the form of good will. Likewise, the owner of shares in a close corporation may encounter difficulties in finding a market for his shares in addition to valuation problems.

Since an executor or administrator traditionally does not have authority to continue a decedent's business, see cases cited notes 17-19 infra, he normally will be forced to liquidate the business at a substantial loss. Even to the extent that modern statutes permit a continuation of a decedent's business in the course of winding up his estate, see note 10 infra, the time limit usually involved magnifies the market and valuation problems encountered by the owner.

- Although tax considerations are beyond the scope of this comment, they nevertleless warrant some attention because of the crucial role which they may play in the selection of the trust device to continue a business. Among the principal nontax reasons for employment of the trust device are: (l) temporarily, to preserve the value of the assets for the sale of inventory in the normal course of business or the going concern value of the business with a view toward preventing sacrificial disposition; (2) permanently, to ensure a continuing income for the designated beneficiaries at a rate which normally will exceed that obtainable from other investments.

Since such motives are in no way inconsistent with the retention of direct control by the owner of the business for as long as he is able, a testamentary trust will normally be employed. However, an owner who wished to preserve the business for minor children or one willing to forego total control in order to remove business earnings from his gross income and to-incur the gift tax rather than the higher estate tax could employ an inter vivos trust. Mehlman, Planning for Continuation of a Business Interest, 1966 INs. L.J. 92. See generally Lowndes \& KRAMER, FEDERAL EstaTe AND GIFT TaXes $\$ \$ 39.1-.6$ (2d ed. 1962). By appointing himself a trustee in the latter instance, the owner-settlor could retain some control over the management of the business. Hawkins, Planning the Form of the Gift, Family Tax Planning for the Owners of a Small Business, 13 W. REs. L. REv. 300, 309-11 (1962). But see INT. REv. CODE of 1954, \$677 (b). In a corporate context the permissible controls would seemingly encompass voting the stock and serving as a director or officer. Cf. INr. REv. CODE of 1954, $\S 671,675$ (4); compare Helvering v. Safe Deposit \& Trust Co., 316 U.S. 56 (1942).

Where a testamentary trust is employed, the tax advantages available in passing on a proprietorship or corporate interest are comparable to those of non-business interests. INT. REV. CODE of 1954, $\$ \S 2031,2033$. By use of one or more life estates and remain$\operatorname{der}(s)$ over, only one estate tax will be imposed prior to disposition by the remainderman. See Lowndes \& KRAMER, op. cit. supra $\$ \S 4.9$, 41.1; Gray \& Low, How to Save Taxes Through Family Trusts, I P-H TAX IDEAs REP. ๆ 13,009.2 (1965).

Where a close corporation is involved, however, the planner must weigh some clearly disadvantageous results of employing the trust device. First, use of the trust form would preclude qualification for or terminate a prior election under Subchapter S. INT. REv. CODE of 1954, $\S 137$ I (a). Poor timing as to the effective date of the coinmencement of the trust could accumulate up to twenty-three months of income from a Subchapter $S$ corporation into one taxable year of the estate. INT. REv, CoDE OF 1954, § 1372; Strasburger, How to Plan the Disposition of Business Interests at Death, 2 P-H TAX IdeAs ReP. I 26,002.3 (1964). Secondly, while a loss suffered in relation to business stock qualifying under $\S 1244$ may be treated as an ordinary loss when held by an individual, INT. REv. CODE of 1954, $\S 1244$ (a)- (c), such a loss is denied this favored treatment when the stock is held by a trust. Strasburger, supra. Finally, if the corporation involved does not declare dividends or otherwise "is not likely to be income producing during the life of the surviving spouse," the settlor will have difficulty claiming the benefit of a marital deduction under either the gift or estate tax provisions. Treas. Reg. $\$ 20.2056$ (b)-5 (f) (1958). In order to overcome this difficulty without having to grant the spouse a power to compel conversion of the trust corpus into more productive assets, the settlor can transfer the business into a non-qualifying trust and transfer 
to avoid a disadvantageous sale of his business and to provide a greater income from his beneficiaries ${ }^{6}$ while insulating them from liability. ${ }^{7}$ Further, the present body of competent professional trustees in the United States should make the prospect of leaving a business in trust even more attractive. Institutionalized methods of research, data processing, efficiency, and widespread contact with the relevant economic community place the professional trustee in an ideal position to handle business interests successfully. ${ }^{8}$

Irrespective of the ability of an individual trustee, the ultimate success of a business left in trust will depend upon whether the basic concepts of trust law are adaptable to the exigencies of business. The purpose of this comment is to consider whether the status of a trustee is compatible with the role of an entrepreneur. Necessarily accompanying this undertaking is the establishment of some guidelines for trustee action in the business world.

\section{A. Undertaking the Business}

At the outset, the prospect for successful administration of the business may be assessed with reference to four basic factors: (1) proper authorization to carry on the business; (2) the standards to which the trustee must conform his administration; (3) the assets available to carry on the business; (4) the extent to which the trustee must personally perform the requisite acts of administration.

(1) Authority. A trustee may derive his authority from the

income-producing assets into the marital deduction trust. Scharfy, Problems Relating to: Redemption of Stock in the Family Business; Income in Respect of a Decedent; Marital Deduction Considerations, I3 W. REs. L. REv. 346, 355 (1962).

For a comprehensive discussion of planning factors involved in the disposition of business interests, see Professor Polasky's series of articles: Planning for the Disposition of a Substantial Interest in a Closely Held Business (pts. 1-3), 44 Iowa L. REv. 83 (1958), 45 Iowa L. Rev. 46 (1959), 46 Iowa L. REv. 516 (1961).

- An interesting case in point is Holmes v. Hrobon, 93 Ohio App. 1, 103 N.E.2d 845 (1951), aff'd in part, rev'd in part, 158 Ohio St. 508, 110 N.E.2d 574 (1953), in which decedent's laundry business, valued at almost 90,000 dollars for inheritance tax purposes, returned 32,000 dollars of net income per year to the income beneficiary of the trust. It would have taken 640,000 dollars invested in normal trustee investments to achieve a like result. Krasnowiecki, Existing Rules of Trust Administration: $A$ Stranglehold on the Trustee-Controlled Business Enterprise, I: The Unincorporated Business, 110 U. PA. L. REv. 506, 515-16 (1962).

${ }^{7}$ See generally 3 ScoTr, TRUSTs $\$ \S 274-79$ (2d ed. 1956) [hereinafter cited as ScoTr].

${ }^{8}$ See Becker, $A$ Lawyer's Challenge on Trustee Management of Family Businesses, 100 Trusts \& EStates 506 (1961); Smith, How to Operate a Business, 98 Trusts \& ESTATES 1141 (1959). 
trust instrument, ${ }^{9}$ statute, ${ }^{10}$ or consent of all interested parties. ${ }^{11}$ In the absence of proper authorization, he is absolutely liable for all losses sustained in carrying on the business and must account for all profits. ${ }^{12}$

While it is generally recognized that a business may properly be the subject matter of a trust, ${ }^{13}$ courts have been consistently reluctant, whatever the alleged source of authority, to permit a trustee to operate a business. ${ }^{14}$ This attitude is based upon the belief that normal fluctuations of business fortune are so unpredictable that a trustee should not risk trust funds in such an investment, ${ }^{15}$ that the

- See, e.g., Moore v. McFall, 263 Ill. 596, 105 N.E. 723 (1914); Mann v. PeoplesLiberty Bank \& Trust Co., 256 S.W.2d 489 (K.y. 1953); Willis v. Sharp, 113 N.Y. 586, 21 N.E. 705 (1889); In the Matter of Estate of Ebbett, 144 Misc. 260, 267 N.X. Supp. 268 (Surr. Ct. 1938); Atkinson, Wills § 121 (2d ed. 1953).

${ }^{10}$ Some of this legislation provides that executors and administrators may continue a decedent's business for a limited time for the purpose of expediently settling the estate. E.g., ILL. REv. STAT. ch. 3, §213a (Supp. 1965); Iowa Code ANN. § 633.83 (1964); R.I. Gen. LAws ANN. § 33-9-7 (1956); TEX. Prob. CODE ANN. $\$ 238$ (1956). Other statutes allow possible indefinite continuation upon application to the proper court for permission. Kan. Gen. Stat. AnN. §59-1402 (1963); OHo Rev. Code Ann. §2113.30 (Page 1953).

This comment is primarily concerned with continuation by a trustee for the latter purpose while the statutes generally apply to executors and administrators in the context of their duty to settle and distribute the estate of a deceased. Yet since indefinite continuation is possible in any event and because an executor or administrator is in any case governed by trust law, Jacob, Trusts for Continuing a Decedent's Business, 18 IowA L. REv. 43, 52 \& n.24 (1932), trust principles elicited in this comment are relevant for a representative actiug under any statutory authority to continue a decedent's business.

11 The generic plrrase "interested parties" includes the decedent's creditors and distributees. The consent required may take the form of explicit agreement. See, e.g., Daniel v. Bank of West Point, 147 Ga. 695, 698, 95 S.E. 255, 256 (1918): "If a testator can give legal direction as to the management of his estate after lis death, there scems to be no reason why the legal and equitable owners of an estate . . . cannot do the same thing by directing the operation of the business after all the debts of the estate are paid, to the extent of their own interest."

Furthermore, interested parties may be foreclosed from asserting an executor or administrator's lack of authority and consequent liability for losses by the knowing acceptance of benefits accruing from a representative's unauthorized continuation of a decedent's business. See, e.g., In re Hemshorn's Estatc, 184 Ore. 365, 198 P.2d 597 (1948) (creditors); Parry's Estate, 244 Pa. 93, 90 Atl. 443 (1914) (beneficiary).

12 See, e.g., Cates v. Cates, 268 Ala. 6, 104 So. 2d 756 (1958); Cochran v. City of Nome, 10 Alaska 425 (Dist. Ct. 1944); Peterman v. United States Rubber Co., 221 Ill. 581, 77 N.E. 1108 (1906); Root's Estate v. Blackwood, 120 Ind. App. 545, 94 N.E.2d 489 (1950); In the Matter of Estate of Ferrante, 190 Misc. 788, 74 N.Y.S.2d 778 (Surr. Ct. 1947); In re Jennings Estate, 74 Mont. 449, 241 Pac. 648 (1925).

${ }^{13}$ See generally BOGERT, TrusTs \& TrusteEs $\$ 112$ (2d ed. 1960) [hereinafter cited as BOGERT]; I SCOTT $\$ 74.1$.

14 See cases cited notes 15-17 infra.

${ }^{15}$ See, e.g., Eufaula Nat'l Bank v. Manasses, 124 Ala. 379, 382, 27 So. 258, 259 (1900); Sebree v. Rosen, 349 S.W.2d 865, 888 (Mo. 1962). See notes 95-106 infra and accompanying text for discussion of traditional treatment of investments in business. 
knowledge and skill required to operate a business are beyond the expected capacity of the average trustee, ${ }^{16}$ and that continuing a decedent's business is fundamentally at odds with the proposition that one's creditors are entitled to immediate satisfaction of their claims at his death. ${ }^{17}$ Reflecting their apprehension, courts require that authority from the settlor be granted in "direct, explicit and unequivocal language"18 and strictly construe any ostensibly relevant language..$^{19}$ Similarly, most statutory provisions sanction continuation of a decedent's business only for such time as is necessary for the expedient winding-up of his estate. ${ }^{20}$ Furthermore, obtaining the consent of all interested parties may present certain practical difficulties. ${ }^{21}$

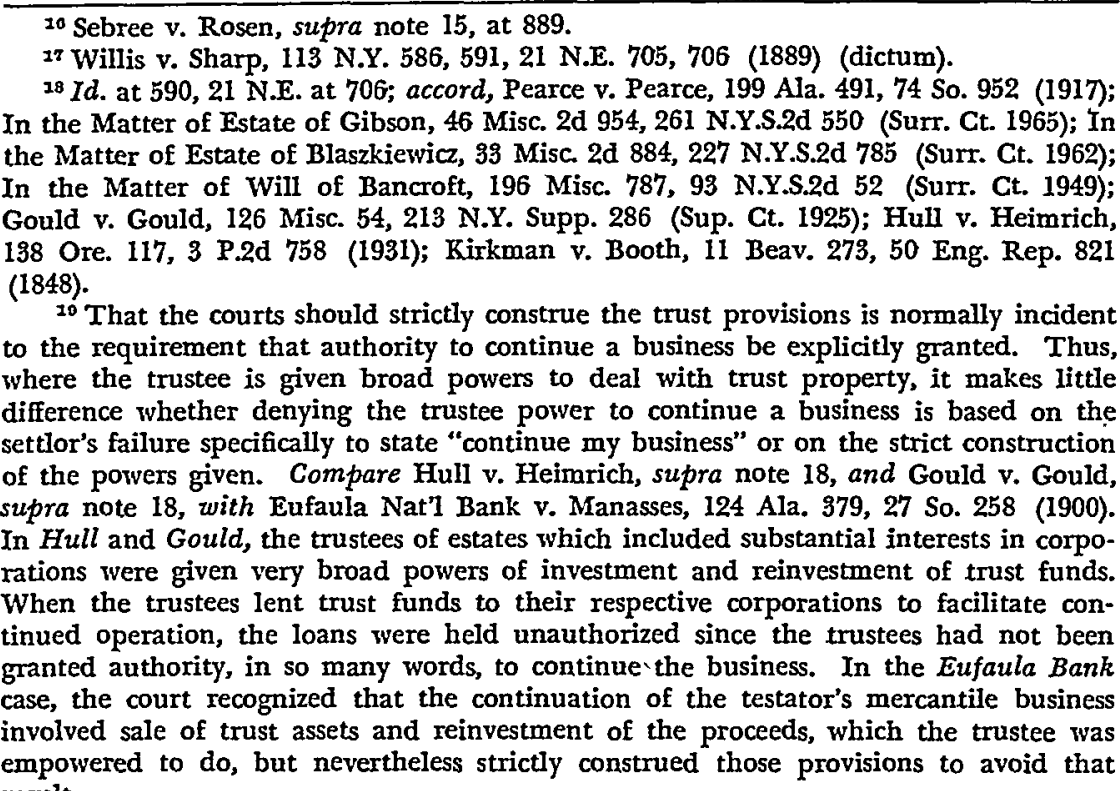
result.

However, more illustrative of the extent of judicial reluctance to allow a trustee to continue a business are cases where authority seemingly is granted in specific terms but is construed away. In the Matter of Kohler, 231 N.Y. 353, 132 N.E.i114 (1921), held that explicit authority "to continue any business now owned and carried on by me [testator]" did not constitute authority to manage corporations which were allied with the testator's sole proprietorship and in which the testator owned a majority share, since the corporations did not constitute a business owned and carried on by the testator. But cf. In re Perloff's Will, 209 N.Y.S.2d 30 (Surr. Ct. 1960).

Saperstein v. Ullman, 49 App. Div. 446, 63 N.Y. Supp. 626 (1900), aff'd, 168 N.Y. 636, 61 N.E. 553 (1901), which held that testatrix' provision that "It is my wish that $m y$ husband [executor] continue the clothing business as now conducted" was merely precatory and therefore did not authorize him to continue the business.

${ }^{20}$ See note 10 supra.

${ }^{21}$ For example, creditors and distributees may be difficult to ascertain or, having 
(2) Standard of Care. Once the trustee is established as the operator of a business, his acts are governed by the judicially developed "prudent man" rule. According to this standard, the trustee must exercise such care and skill in dealing with the trust as would an ordinary prudent man dealing with his own property. ${ }^{22}$ The trustee's acts are assessed according to an objective standard ${ }^{23}$ applied

been ascertained, may withhold consent, doubting the ability of the representative. While these facts do not foreclose the representative from continuing a business, he will be responsible for any diminution in the value of the assets at the time of the decedent's death. See notes 11-12 supra and accompanying text.

${ }^{22}$ See, e.g., Wilmington Trust Co. v. Coulter, 41 Del. Ch. 548, 200 A.2d 441 (Sup. Ct. 1964); Clark v. Tennessee Chem. Co., 167 Ga. 248, 145 S.E. 73 (1928); Harris Trust \& Sav. Bank v. Wanner, 393 I11. 598, 66 N.E.2d 867 (1946); Blauvelt v. Citizens Trust Co., 3 N.J. 545, 71 A.2d I84 (1950); In the Matter of Will of Mendleson, 46 Misc. 2d 960, 261 N.Y.S.2d 525 (Surr. Ct. 1965); In re Patchogue Citizens Bank \& Trust Co., 89 N.Y.S.2d 208 (Sup. Ct. 1949); In re Parks' Trust, 39 Wash. 2d 763, 238 P.2d 1205 (I951); Restatement (Second), Trusts \$174, comment a (1959). But see In the Matter of Estate of Cook, 20 Del. Ch. 123, 171 Atl. 730 (Ch. 1934); In re Whiteley, 33 Ch. D. 347 (1886) (opinion of Lindley, L. J.), aff'd sub nom. Learoyd v. Whiteley, 12 App. Cas. 727 (1887). In Whiteley, the court stated: "A trustee ought to conduct the business of the trust in the same manner that an ordinary prudent man of business would conduct his own .... [I]n applying [the rule] ... care must be taken not to lose sight of the fact that the business of the trustee, and the business which the ordinary prudent man is supposed to be conducting for himself, is the business of investing money for the benefit of persons who are to enjoy it at some future time, and not for the sole benefit of the person entitled to the present income. The duty of a trustee is not to take such care only as a prudent man would take if he had only himself to consider; the duty rather is to take such care as an ordinary prudent man would take if he were minded to make an investment for the benefit of other people for whom he felt morally bound to provide." $33 \mathrm{Ch}$. D. at 355 . In Cook, the court repeated the Restatement rule of care, cited Whiteley, and observed: "In other words he must take no risks which would not be taken by an ordinarily prudent man who is trustee of another person's property." 20 Del. Ch. at 126, 171 Atl. at 731. (Emphasis added.)

The rule of Whiteley and Cook is different from the textual statement to the extent that the element of cautious conservation, in addition to reasonable care and skill, is injected into the standard of care. See 3 Scort $\$ 227.3$; note 101 infra. The distinction is between a general statement of a trustee's standard of care and the particular crystallization of that standard with reference to trustee investments. It would seem inappropriate to state the general rule of care in the same terms as are applied to investment situations since there is no necessity to require the added element of cautious conservation in a trustee's non-investment transaction. (For an argument indicating it makes little sense to include the conservation element even in an investment situation, see note 112 infra).

Therefore, it appears that a trustee charged with continuing a business must, in general, conduct himself as would a reasonably prudent businessman engaged in a similar operation. See Palmer v. Moore, 82 ${ }^{\circ}$ Ga. 177, 8 S.E. 180 (1888); In the Matter of Friedlander, 189 App. Div. 90, 178 N.Y. Supp. 50 (1919). Yet when the trustee engages in a transaction involving an outlay of funds for the improvement or expansion of the business, there is evidence that the courts will apply the Whiteley rule to his conduct. See notes 91-94 infra and accompanying text for a further consideration of this problem.

${ }^{28}$ See, e.g., Knox v. MacKinnon, 13 App. Cas. 753, 766 (1888); RESTATEMENT (SECOND), TRUsTs $\S 174$, comment $a$ (1959); 3 ScoTr $\S 227$, at 1661 . 
to the circumstances existing and reasonably foreseeable when the trustee acted. ${ }^{24}$ The trustee is liable for any injury or loss to the trust occurring through his failure to act with the requisite circumspection. ${ }^{25}$

(3) Assets. Whether the trustee has sufficient funds to operate his business is of fundamental importance. Primary sources of such assets are funds earmarked by the settlor for use in the business and the general funds of the settlor's estate. Access to these sources is limited by the settlor's intent. ${ }^{26}$ It is generally held that a simple authorization to continue a business indicates no more than that the trustee may utilize only those assets committed to the business at the settlor's death.27 Access to these sources is further limited by the

24 See, e.g., Wilmington Trust Co. v. Coulter, 41 Del. Ch. 548, 200 A.2d 441 (Sup. Ct. 1964); In the Matter of Will of Mendleson, 46 Misc. 2d 960, 261 N.Y.S.2d 525 (Surr. Ct. 1965); In re Patchogue Citizens Bank \& Trust Co., 89 N.Y.S.2d 208 (Sup. Ct. 1949); In te Parks' Trust, 39 Wash. 2d 763, 238 P.2d 1205 (1951); RestatemENT (SECOND), TRUsTs $\S 174$, comment $b$ (1959); 3 ScoTr $\S 227$, at 1662 .

${ }^{25}$ See generally 2 id. $\$ 201$. To a limited extent, a settlor may relax the standard to which his trustee would normally he held by inserting exculpatory provisions in the trust instrument. However, courts generally place a strict construction upon such provisions. See Restatement (SECOND), TRUsts $\$ 222$, comment $a$ (1959); 2 ScoTr $\$ 222.2$; Shinn, Exoneration Clauses in Trust Instruments, 42 Yale L.J. 359 (1933); Comment, Directory Trusts and the Exculpatory Clause, 65 ColvM. L. REv. 138, 141 (1965); Note, Trusts: Effect of Exculpatory Clause, 26 CoRNELl L.Q. 165 (1940). The reason for this attitude is that the obligation to conform to a minimal standard of conduct is inherent in the very nature of a trust relationship and may not be bargained away by the parties to a trust. Thus, an exculpatory provision may not go so far as to excuse liability for self-dealing, bad faith, gross negligence, and reckless indifference to the interests of the beneficiaries. See authorities cited supra. Compare UNIFORM TRUSTS AcT $\$ \S 3.5,17$.

${ }^{20}$ E.g., Burwell v. Cawood, 43 U.S. (2 How.) 559 (1884); Pitkin v. Pitkin, 7 Conn. 307 (1829); Moore v. McFall, 263 IIl. 596, 105 N.E. 723 (1914); Willis v. Sharp, 113 N.Y. 586, 21 N.E. 705 (1889); In the Matter of Estate of Gibson, 46 Misc. 2d 954, 261 N.Y.S.2d 550 (Surr. Ct. 1965); Furst v. Armstrong, 202 Pa. 348, 51 Atl. 996 (1902); Ex parte Garland, 10 Vesey Jr. 110, 32 Eng. Rep. 786 (Ch. 1804).

${ }^{27}$ Burwell v. Cawood, supra note 26; Pitkin v. Pitkin, supra note 26; Moore v. McFall, supra note 26; Willis v. Sharp, supra note 26; In the Matter of Estate of Gibson, supra note 26; Ex parte Garland, supra note 26. Contra, Furst v. Armstrong, supra note 26.

One basic factor to which the courts look in ascertaining the settlor's intent is the existence of other particular devises, bequests, and legacies. The manifest inconvenience which would result if legacies and so forth had to be called back to satisfy the debts incurred in the continuation of the settlor's business prompted the Supreme Court, in Burwell v. Cawood, supra note 26 , to assert: "[N]othing but the most clear and unambiguous language, demonstrating in the most positive manner that the testator in. tends to make his general assets liahle for all debts contracted in the continued trade after his death, and not merely to limit it to the funds embarked in that trade, would justify the court in arriving at such conclusion." 43 U.S. (2 How.) at 577.

Another factor considered by the courts in determining intent is the hazard involved in carrying on a business. See Willis v. Sharp, supra note 26, at 591, 21 N.E. at 706. However, where there are no legacies and authority to continue a business is conferred, the trustee will generally have resort to the general assets of the estate if he is given broad powers of management. See Moore v. McFall, supra note 26. 
possible diminution or depletion of the settlor's estate by creditors exercising their right to immediate satisfaction of their claims upon his death. ${ }^{28}$

A scarcity of estate capital may necessitate resort to additional methods of raising sufficient funds to continue the business. The most common method is mortgaging trust property. The trustee must be able to support his incumbrance-creating transaction by authorization from the express or implied terms of the trust instrument or from a statute. ${ }^{2 \theta}$

(4) Delegation. For various reasons, the trustee may not wish to take active part in the conduct of the business. ${ }^{30}$ However, it is familiar trust doctrine that a trustee may not delegate certain acts and duties to another without becoming absolutely liable for any losses caused by the delegatee's act. ${ }^{31}$ Because the settlor seemingly placed great faith in the trustee's talent and capabilities by charging him with the care of his property, ${ }^{32}$ it is generally held that the trustee must personally perform those acts and duties which require the exercise of discretion, while those merely "ministerial" in nature may be delegated to an agent. ${ }^{33}$ Professors Scott ${ }^{34}$ and Bogert ${ }^{35}$

${ }^{28}$ See, e.g., Willis v. Sharp, supra note 26.

${ }^{20}$ See gevierally 2 ScoTr $\$ 188.5$.

${ }^{30}$ For example, the trustee may be inexperienced in the particular type of business involved in the trust; he may wish to groom a member of the settlor's family for eventual ownership of the business; he may be engaged in other activities which interfere with his opportunities for constant supervision of the business.

Professional trustees have complained that normal compensation, see note 83 infra, is inadequate for the time, talent, and responsibility of continuing a business in trust. See, e.g., Cowdery, Basis of Compensation for Handling Businesses in Trust, Trust Bull., June 1957, p. 2; Wilkins, Trustee's Compensation for Handling Businesses in Trust, 99 Trusts \& Estates 12 (1960); 10 AustL. L.J. 144 (1936).

${ }^{81}$ See, e.g., Law v. Bush, 239 Ala. 612, 195 So. 885 (1940); Bates v. Jones, 224 Ala. 82, 139 So. 242 (1932); In re Wood's Estate, 159 Cal. 466, 114 Pac. 992 (1911).

Delegation carries another important sanction. For example, a trustee will not be permitted to subject the trust to the expense of hiring an agent to accomplish that which the trustee is reasonably expected to perform personally. See, e.g., In the Matter of Estate of Sellers, 31 Del. Ch. 158, 181-82, 67 A.2d 860, 871 (Ch. 1949). The question arises whether the "expenses" rule differs from the "absolute liability" rule. It has been asserted that the two are to be distinguished. Note, Delegation of Fiduciary Duties, 46 Iowa L. REv. 127, 128-29 (1960). Yet it appears that in either case, the same test-the rule of prudence-is being administered. See notes 34.36 infra and accompanying text.

${ }^{22}$ See, e.g., Gaines v. Dahlin, 228 Ala. 484, 488-89, 154 So. 101, 104 (1934); Trustees of Rutgers College v. Richman, 41 N.J. Super. 259, 288, 125 A.2d 10, 26 (Ch. 1956); Woddrop v. Weed, 154 Pa. 307, 315, 26 Atl. 375, 377 (1893).

${ }^{38}$ E.g., Garrett v. First Nat'1 Bank, 233 Ala. 467, 172 So. 611 (1937); North American Trust Co. v. Chappel, 70 Ark. 507, 69 S.W. 546 (1902); Spengler v. Kuhn, 212111. 186, 72 N.E. 214 (1904); Ball v. Consolidated Realty Co., 246 Ky. 458, 55 S.W.2d 60 (1932); Herr v. United States Cas. Co., 347 Pa. 148, 31 A.2d 533 (1943); West v. 
point out that nearly any act involves the exercise of some discretion and that the distinction between valid and invalid delegation is properly understood as an application of the "prudent man" rule. ${ }^{36}$ Thus, if a reasonably prudent man engaged in a task similar to the trustee's would entrust the accomplishment of certain acts to an agent, ${ }^{37}$ the trustee may do so also. ${ }^{38}$

On any reasonable analysis, it would appear that the trustee could not be expected to handle every minute detail of operating a settlor's business. ${ }^{38}$ It is equally clear that the trustee may not completely divorce himself from supervision of the business. ${ }^{40} \mathrm{Be}$ tween these extremes the determination of "reasonableness" depends upon the individual circumstances of each case. Without attempting to assess all the possible situations, it is helpful to outline some basic areas of difficulty and to assess judicial approaches to them. For purposes of discussion, it is expedient to distinguish between trustee management of an individually owned enterprise and an incorporated business.

When the trustee is charged with continuing an individually owned enterprise, the basic issues are whether he must personally undertake the day-to-day transactions of the business or whether he may employ a manager, and in the latter event, what degree of

Hapgood, I4l Tex. 576, 174 S.W.2d 963 (1943); Meck v. Behrens, 141 Wash. 676, 252 Pac. 91 (1927).

st 2 SCOTT $\$ 171.2$, at 1280 .

ss BOGERT $\$ 555$, at 57 .

${ }^{80}$ See, e.g., Walters-Southland Institute v. Walker, 222 Ark. 857, 263 S.W.2d 83 (1954); McLean v. Peyser, 169 Md. I, 179 Atl. 58, cert. denied, 296 U.S. 638 (1935); Indian Head Nat'l Bank v. Thierault, 97 N.H. 212, 84 A.2d 828 (1951); Dodge v. Stickney, 62 N.H. 330 (1882); Speight v. Gaunt, 22 Ch. D. 727, aff'd, 9 App Cas. 1 (1883).

s7 See cases cited note 36 supra.

${ }^{38}$ Of course, the trustee must use reasonable care in the selection of an agent. See, e.g., Walters-Southland Institute v. Walker, 222 Ark. 857, 263 S.W.2d 83 (1954); In the Matter of Estate of Whipple, 19 N.Y.S.2d 105, 110 (Surr. Ct. 1940); 2 Scorr \$ 225.1.

${ }^{\circ 0}$ See cases cited note 38 supra.

According to the Restatement, factors involved in ascertaining the propriety of delegation are the following: (1) the amount of discretion involved; (2) the character and value of the property involved; (3) whether principal or income is involved; (4) the proximity of the subject matter of the trust; (5) whether the trustee has the requisite skills to perform the act. REsTatement (SEcond), Trusts $\$ 1 / i 1$, comment $d$ (1959). For a catalogue of decisions involving specific fact situations, see Note, 46 Iowa L. REv. 127 (1960).

${ }^{0}$ See Gaines v. Dahlin, 228 Ala. 484, 154 So. 101 (1934); Attorney General v. Olson, 346 Mass. 190, 191 N.E.2d 132 (1963); Milbank v. J. C. Littlefield, Inc., 310 Mass. 55, 36 N.E.2d 833 (1941); In the Matter of Mild, 25 N.J. 467, 136 A.2d 875 (1957); Woddrop v. Weed, 154 Pa. 307, 26 Atl. 375 (1893); Meck v. Behrens, I4l Wash. 676, 252 Pac. 91 (1927). 
control over the business he must maintain. One case, El Boletin Popular Pub. Co. $v$. Springer, 41 squarely raises the delegation issue in the context of a trustee-operated business. In Springer, two printing and publishing companies transferred their physical assets and good will to three trustees with directions to do all that was "necessary and proper" to carry on the publication of a Republican newspaper. The trustees transferred the business premises to a third party under a lease which stipulated that the lessees would carry on the business according to the provisions of the trust instrument and that the lessors might repossess the property in default of any of the provisions. In a suit by the settlors to discharge the trustees for having delegated matters requiring the exercise of discretion, ${ }^{42}$ the court held the trustees' conduct proper inasmuch as they retained means of supervisory control.43 However, the difficult issue, never reached since the settlors admitted that the trust did not impose daily managerial duties upon the trustees, ${ }^{44}$ was whether hiring a manager to conduct the business would have been an improper delegation. Nevertheless, the case is instructive as to the extent of supervisory control a trustee must exercise over a hired manager. ${ }^{45}$

433 N.M. 275, 265 Pac. 713 (1928). The Springer case did not involve the operation of a typical sole proprictorship since the business had been conducted in corporate form. However, the trust consisted of physical assets, not stock, transferred to the trustees by the corporations owning the assets, tbus distinguishing the situation from that which exists when a sole or majority shareholder transfers stock to a trustee with instructions to continue the business. See note 52 infra and accompanying text.

4 The settlors' concept of the duties of the trustees included the following: "That a competent manager should be employed to look after ... details, who would be directly under the control of the trustees, and subject absolutely to their orders, and whose employment would be subject to the will of the trustees, and that the trustees would closely scrutinize all obligations incurred, as well as all plans for the advancement of the business interests of their trust, and would authorize or reject all proposed business policies. In other words [the trustees] ... were to act as a sort of board of directors, whose duty it was to meet regularly and dictate the policies and business principles of the trust, maintaining always a close personal contact and supervision of the business." 33 N.M. at 282, 265 Pac. at 715-16.

is Id. at 282, 265 Pac. at 716.

4 Id. at 282, 265 Pac. at 715. See note 42 supra.

48 Having found that the trustees had not divested themselves of control of the trust by the terms of the lease, see note 43 supra, the court set forth their duties "They" must see that [the lessee] ... . does not involve the trust estate in liability for expense or damage. They must examine his quarterly reports, verify them, and see that possible profits are divided as agreed. They must keep in touch with the news and editorial policies ...." 33 N.M. at 282, 265 Pac. at 716.

Analogizing the lease to a contract for employment of a manager, it would seem that it must not in terms be irrevocable for any any designated period but rather should proyide for termination for failure to comport with the basic purposes of the trust. As to other views on the extent of supervision, see note 59 infra. 
Notwithstanding the settlors' admissions, the court intimated that the extent of delegation of managerial duties was to be decided with reference to reasonableness under the circumstances. ${ }^{46}$ In this case, relevant considerations included the broad provisions of the trust instrument ${ }^{47}$ and the fact that the trustees, living some distance from each other and from the situs of the business, could not conveniently meet to review the operation of the business. ${ }^{48}$

Other circumstances upon which a trustee might rely in predicting the limits of proper delegation include the settlor's former managerial practice, ${ }^{49}$ the methods currently employed by others engaged in operating a similar business on a comparable scale, ${ }^{50}$ and the trustee's possession of the requisite skill for the act in question. ${ }^{51}$

In contrast to the trustee of an individually owned enterprise, the trustee charged with carrying on a corporation does not have plenary managerial control of the enterprise ${ }^{52}$ since the trust res is stock and not the business assets themselves. Therefore, the opportunity for active participation in management is largely dependent on the voting power of his stock. ${ }^{53}$

to 33 N.M. at 281, 265 Pac. at 716. The extent of the court's sympathetic attitude in adopting the reasonableness test may be seen by comparing the result which would have obtained if the court had undertaken to base its decision on a classification of the various activities which execution of the trust entailed. It is difficult to ascertain any elements of publishing a newspaper which are not matters requiring the exercise of "discretion" and, consequently, not subject to delegation. This would seem to be especially the case with respect to the content of editorials and the like.

¿The only specific duties imposed upon the trustees were to render annual reports and to divide profits, if any, equally between the trustors and to conduct the publications as Republican newspapers. Id. at 281, 265 Pac. at 715.

$\$ 8$ Ibid.

4 See Turnbull v. Pomeroy, 140 Mass. 117, 3 N.E. I5 (1885); Herr v. United States Cas. Co., 347 Pa. 148, 31 A.2d 533 (1943).

so The statement in the text follows from the "prudent man" rule, assuming, of course, that evidence of the customary practices of businessmen is generally accepted to ascertain the standard of requisite prudence. Thus, evidence of the manner in which prudent men are dealing with their own property is admissible in justification of a trustee's conduct. E.g., In re Flynn's Estate, 205 Okla. 311, 237 P.2d 903 (1951).

${ }^{51}$ See, e.g., In the Matter of Estate of Sellers, 31 Del. Ch. 158, 67 A.2d 860 (Ch. 1949); In the Matter of Estate of Greata, 172 Misc. 955, 17 N.Y.S.2d 776 (Surr. Ct. 1939). But see In the Matter of Estate of Gutman, 171 Misc. 680, 14 N.Y.S.2d 473 (Surr. Ct. 1937).

${ }^{62}$ In the Matter of Will of Shupack, 1 N.Y.2d 482, 154 N.Y.S.2d 441, 136 N.E.2d 513 (1956).

${ }^{88}$ See In the Matter of Estate of Nicklesburg, 34 Misc. 2d 82, 224 N.Y.S.2d 90 (Surr. Ct. 1961). It is assumed for the purpose of this comment that the settlor or the settlor and the trustee individually own at least a controlling interest in the corporation, since otherwise an instruction that trustees carry on his "business" would be meaningless. 
Assuming, however, that the trustee has sufficient voting power to elect himself to a directorship, the question arises whether failure to do so is an improper delegation of business decisions to persons not parties to the trust.54 The issue is clouded for two reasons. In the first instance, it may be difficult to ascertain exactly what "carrying on" an incorporated business means.55 Furthermore, since the trustee technically is given stock and not physical business assets, there may be logical difficulty in asserting that the trustee, as shareholder, has the power, susceptible of delegation, to make business decisions.

To a large extent, the result of any given case will probably be dependent upon the activities of the settlor prior to his placing the business in trust. Thus, if the trust involves a family corporation of which the settlor was the sole stockholder and the major director, active managerial duties might reasonably be expected of the trustee. ${ }^{57}$ By analogy to the Springer case, ${ }^{58}$ it would appear that, at the very least, the trustee must keep himself informed of the activities

54 The possibility of such a result is suggested by several courts and commentators. See In the Matter of Estate of Kirkman, 143 Misc. 342, 256 N.Y. Supp. 495 (Surr. Ct. 1932) (alternate holding); Elias v. Schweyer, 13 App. Div. 336, 340, 43 N.Y. Supp. 55, 58 (1897) (dictum); Cahn, Estate Corporations, 86 U. PA. L. REv. 136, 137 (1937); Krasnowiecki, Existing Rules of Trust Administration: A Stranglehold on the TrusteeControlled Business Enterprise, II: The Incorporated Business, 110 U. PA. L. REv. 816, 828 (1962); Trachtman, Closely Held Businesses, 90 TRUSTs \& Estates 668, 674 (1951); Comment, Trusts-The Fiduciary Aspects of Estate Corporations, 57 Mich. L. REv. 738, $740(1959)$.

ss Compare In the Matter of Kohler, 231 N.Y. 353, 132 N.E. 114 (1921), with In the Matter of Estate of Kellner, 66 N.Y.S.2d 727 (Surr. Ct. 1946).

The problem is caused by the difficulty in identifying the settlor with a "business." In the Kohler case, the testator had been a director and officer of several corporations of which he owned a majority share. He directed that his trustees continue any business in which he was engaged. The court stated that "the individual influence and ultimate control by a majority stockholder does not in itself constitute in any proper sense a business owned and carried on by such stockholder." 231 N.Y. at 367, 132 N.E. at 117. As an alternative to "carrying on" the settlor's estate, the trustee may simply treat his holding as a normal investment from which he receives dividends payable to the beneficiaries. Under this alternative his duty is simply to retain the investment so long as it remains prudent to do so. If on analysis of the business he finds the investment to be risky, it would be his duty to sell the interest. See cases cited note 105 infra. If, on the other hand, the trustee is to conduct the business, his duty, by inference, would be to do that which is necessary to ameliorate any conditions affecting the financial stability of the business.

se See note 52 supra and accompanying text.

' ${ }^{2}$ Krasnowiecki, Existing Rules of Trust Administration: A Stranglehold on the Trustee-Controlled Business Enterprise, II: The Incorporated Business, 110 U. PA. L. REv. 816, 827-28 (1962); Trachtman, supra note 54, at 674 .

${ }^{8}$ See notes $41-48$ supra and accompanying text. 
of the directors ${ }^{59}$ and in a position to effect changes ${ }^{60}$ and must exercise reasonable prudence in the choice of those who do actually operate the business. ${ }^{61}$

\section{B. Sustaining the Business}

Obsolescence and ordinary use of physical business assets may necessitate the expenditure of trust funds or the creation of contingency reserves to keep the trust property suitable for the efficient carrying on of the business. If the trustee is to avoid bearing general trust expenses personally, ${ }^{62}$ he must have proper authority to incur them. ${ }^{63}$ When maintenance or replacement expenses occur in the trust context, doctrines of "repairs" and "improvements" 64 may hamper the administration of the trustee who continues a business.

It is generally held that a trustee need not be explicitly authorized by the trust instrument to incur expenses for repairing trust property. ${ }^{65}$ This result follows from the trustee's duties to preserve ${ }^{66}$

${ }^{89}$ Consider the position of the Trust Division of the American Banker's Association on the subject of actual management of a business on a day-to-day basis:

"It should be distinctly understood that a controlling interest in a closely held business on either a permanent or temporary basis does not mean that the bank is expected actually to run the business. The role of the bank in most instances is to make sure that adequate management is retained and that the operation of the business is properly supervised for the benefit of the deceased owner's estate.

"In almost every instance it should be the goal of the bank to obtain a key man who is capable of actually managing the business ...." TRUST Drv., AMERTCAN BANKERS Ass'n, HaNdLING Businesses in Trust II (1959). See also, Cowdery, When a Trustee Has a Business to Handle, Trust Bull., June 1958, p. 14; Foulke, How Special Division of Trust Department Handles Closely Held Firms, 100 Trusrs \& Estares 606, 608 (1961) (obtain manager to operate; once a year review of his administration considered sufficient to discharge duty).

${ }^{\circ 0}$ The trustee's major sanction in his supervisory capacity is his voting power. Thus, he must not compromise the exercise thereof by entering into: (1) voting agreements. In re Palmer's Will, 132 N.Y.S.2d 311 (Surr. Ct. 1954). (2) proxy agreements where he is the owner of a controlling share of the stock. See 2 Scort $\$ 193.3$, at 1465.

${ }^{61}$ In re Koretzky's Estate, 8 N.J. 506, 86 A.2d 238 (1951).

02 See note 25 supra and accompanying text.

os See 2 Scort $\S 188$.

os For a discussion of improvements, see notes 85-94 infra and accompanying text.

${ }^{6}$ E.g., In re Boyd, 231 Iowa 1325, 4 N.W.2d 387 (1942); Maynard v. Columbus, 150 Ky. 817, 819, 150 S.W. 1019, 1020 (1912).

${ }^{\circ 8}$ See Whittingham v. Schoefield's Trustee, $23 \mathrm{Ky}$. L. Rep. 2444, 6l S.W. 846, modified, 68 S.W. 116 (Ct. App. 1902); Martin v. Eslick, 229 Miss. 234, 90 So. 2d 635 (1956), corrected, 229 Miss. 261, 92 So. 2d 244 (1957); Annett-Mahnken Realty Co. v. Gollin, 110 N.J. Eq. 469, 160 Atl. 400 (1932); In the Matter of Will of Lavery, 79 N.Y.S.2d 27 (Surr. Ci. 1948) (dictum), aff'd mem., 275 App. Div. 674, 87 N.Y.S.2d 221 (1949); In the Matter of Estate of Farrell, I52 Misc. 118, 272 N.Y. Supp. 852 (Surr. C.. 1933); Parry's Estate, 244 Pa. 93, 90 Atl. 443 (1914). 
trust property and to make it productive. ${ }^{67}$ Generally stated, the trustee is allowed to make those repairs reasonably necessary to preserve trust property, ${ }^{68}$ a result derived from application of the "prudent man" standard.69 While the foregoing is orthodox theory and would undoubtedly lead to liberal recognition of the power to make whatever alterations serve the best interests of the trust, ${ }^{70}$ it is believed that judicial attitudes and the actual decision-making processes are often conditioned by other historical factors. Thus, it may be suggested that when the courts determine the propriety of repairs the underlying consideration is actually whether the beneficiary reasonably ought to be charged with the particular expense. Support for this view is indicated by the fact that the decisive issue in most cases regarding trustee expenditures for altering trust property is not really a question of the power to incur the expense; rather, the authority to charge an expenditure to the corpus or the income of the trust is the crucial point. ${ }^{71}$

Apparently, the rules as to the allocation of alteration expenses developed in the context of the rules governing the right of legal life tenants and remaindermen. ${ }^{72}$ A legal life tenant has the duty to prevent deterioration of the estate at his own expense. ${ }^{73}$ Similarly, it is the settled trust rule that expenses for repairs are payable out of income..$^{74}$ However, since a legal life tenant is obliged only to prevent waste, ${ }^{75}$ it is easy to understand that an income beneficiary's self-interest would prevent the trustee from charging him with more

\footnotetext{
${ }^{87}$ See Spooner v. Dunlap, 87 N.H. 384, 180 Atl. 256 (1935).

${ }^{\circ 8}$ See Whittingham v. Schoefield's Trustee, 23 Ky. L. Rep. 2444, 2447, 67 S.W. 846, 848, modified, 68 S.W. 116 (C.. App. 1902).

For a catalogue of those alterations which have been classified by courts as "repairs," see BOGERT $\S 600$, at 356 .

${ }^{a}$ Whittingham v. Schoefield's Trustee, supra note 68 , at 2447,67 S.W. at 848.

${ }^{70}$ See In re Boyd, 231 Iowa 1325, 1332, 4 N.W.2d 387, 392 (1942) (dictum).

${ }^{71}$ Russell v. Rusell, 109 Conn. 187, 193-94, 145 Atl. 648, 651 (1929).

72 See, e.g., Estate of Cole, 102 Wis. 1, 9, 78 N.W. 402, 405 (1899); 2 PERRY, Trusts \& TRUSTEFs $\$ 477 b$ (7th ed. 1929); Krasnowiecki, Existing Rules of Trust Administra. tion: A Stranglehold on the Trustee-Controlled Business Enterprise, I: The Unincorporated Business, 110 U. PA. L. REv. 506 (1962).

${ }^{88}$ E.g., Superior Oil Corp. v. Alcorn, $242 \mathrm{Ky} .814,47$ S.W.2d 973 (1931); Prescott v. Grimes, 143 Ky. 191, 136 S.W. 206 (1911); In re Hubbell's Will, 302 N.Y. 246, 97 N.E.2d 888 (1951).

"See 3 ScoTr $\$ 233.3$, at 1757 .

${ }^{85}$ The trustee's duty to preserve is clearly analogous. See note 68 supra and accompanying text.
} 
than his legal counterpart could be compelled to pay in an action for waste. ${ }^{78}$ It should not be understood, however, that the rights of legal life tenants and income beneficiaries correspond precisely. Often, an income beneficiary will be forced to bear the cost of alterations which normally would be allocated to the corpus of the trust, since circumstances may exist in which it is both equitable and necessary to utilize income instead of corpus if the trust is to achieve its purposes. ${ }^{77}$ Nevertheless, it does appear that the analogy to waste is at least one factor behind the rule that repairs may be made to preserve trust property.

To permit a trustee to take only those measures calculated to preserve trust property or cause it to produce a reasonable income does not usually hinder trustee administration of rental realty. Since land is a basic and limited commodity, a minimum of piecemeal repairs should re-attract any tenants who may have been initially repelled by the condition of the premises. However, because of stiffer competition and fluctuating consumer desires, the trustee in the business of selling goods or services may never recover from an economic lapse induced by the forced retention of old assets until the last bit of profit can be squeezed from them. ${ }^{78}$

In theory, however, it should not be difficult to surmount the traditionally required showing of immediate necessity, since the trustee must administer his trust with the prudence of a reasonable man. ${ }^{79}$ Proper emphasis on the necessities of business would make the long-term interests of the beneficiaries the relevant index to the propriety of the trustee's expenditures. Thus, the trustee could show that while the business may at any given time be in reasonable physical repair and returning a reasonable income, unless it keeps

${ }^{\circ 0}$ Compare 2 Perry, Trusts \& Trustees $\$ 477$, at 814 (7th ed. 1929).

${ }^{77}$ Utilization of trust income may be necessary where substantial expenditures for alterations normally classifiable as "improvements" cannot be supported by the principal and yet are needed in order to make the trust productive. See In the Matter of Will of Ambrose, 12 App. Div. 2d 687, 207 N.Y.S.2d 930 (1960) (memorandum decision).

${ }^{78}$ An illustration of the consequences of a failure to modernize is the present situation of American Motors, Inc. A decade ago, this corporation seemed in fine financial condition: profits were good and the management used them to pay off all obligations and to supplement shareholder dividends. The company now finds itself in economic straits. Experts attribute its current condition to the fact that management of a decade ago neglected to utilize the profits on a planned program of updating their operation to maintain the company's competitive position. See Time, Jan. 28, 1966, p. 79.

70 See note 69 supra and accompanying text. 
pace it may eventually lose its competitive position. Such a result would preclude the possibility of any income or at least necessitate drastic and expensive rehabilitative measures. ${ }^{80}$ This argument is further supported by the observation that common business practice involves the maintenance of reserves for depreciation. ${ }^{81}$

\footnotetext{
${ }^{80}$ See In re Boyd, 231 Iowa 1325, 4 N.W.2d 387 (1942). In Boyd, the trustee held property which included a fifty-year-old farm house; he proposed to make substantial alterations of the house-removal of a porch, re-siding the house with asbestos, reduction of the size of windows, re-flooring, replastering-at a cost of $\$ 1,457.60$ to be paid from the income of the trust. Objecting, the income beneficiary alleged that the proposed repairs were unnecessary to put the house in rental condition and that any repairs absolutely necessary could be made at a cost of $\$ 300$. The court held that the trustee was justified in making the proposed alterations and charging the cost to the income beneficiary, finding that the question was "whether the repairs should be made piece. meal, which undoubtedly the trustee has a right to do, or whether they should be made now .... The longer the making of such necessary repairs is postponed, the greater will be the expense when made." Id. at 1331, 4 N.W.2d at 391.

81 There is some question though as to whether trustees may properly reserve income in anticipation of repairs. See 3 Scort \$239.4; Copron, Reserves Against the Depreciation of Real Property Held by a Trustee, 12 OH10 ST. L.J. 565 (1951). With regard to buildings held in trust the failure of some courts to sanction any plan for reserves is posited on the premise that buildings do not depreciate in any real sense. See 3 Scort, $\$ 239.4$, at 1870; Krasnowiecki, Existing Rules of Trust Administration: A Stranglehold on the Trustee-Controlled Business Enterprise, I: The Unincorporated Business, 110 U. PA. L. REv. 506, 532 (1962). Nevertheless, if the trust consists of a going business, there should be no impediment to the reasonable reservation of income to meet depreciation expenses. See Rafferty v. Parker, 241 F.2d 594 (8th Cir. 1957); In re Trust of Bailey, 241 Minn. 143, 62 N.W.2d 829 (1954); Re Rose [1940] 1 D.L.R. 139 (N.B.); Re Robertson [1951] 3 D.L.R. 241 (Ont.).

For an excellent discussion of the basis of American decisions against trustee reserves, see Krasnowiecki, supra at 522-32.

As to a settlor's corporation, it is commonly held that retention of earnings for reserves, rather than payment by way of dividends to the beneficiaries, is improper. In the Matter of Estate of Adler, 164 Misc. 544, 299 N.Y. Supp. 542 (Surr. Ct. 1937); In the Matter of Estate of McLaughlin, 164 Misc. 539, 299 N.Y. Supp. 559 (Surr. Ct. 1937). Contra, Green v. Philadelphia Inquirer Co., $329 \mathrm{~Pa} .169,175,196$ Atl. 32, 34 (1998) (dictum). The problem is whether the courts should treat the corporation merely as a device utilized to administer the settlor's investments, in which case normal rules of trust administration would apply, or whether the corporation should be considered as an entity unto itself. If the latter approach is adopted, the propriety of a trustee's participation in a decision not to declare dividends would be decided with reference to corporate law and the trustee-director's duty to the corporation as a whole. See Cahn, supra note 54, at 136; Comment, 57 Mick. L. REv. 738, 746.47 (1959). The present state of the law indicates that the trustee commits a breach of trust in failing to prevent the accumulation of reserves depending upon whether he owns all the stock or only a controlling portion thereof. Compare Rosencrans v. Fry, 21 N.J. Super. 289, 91 A.2d 162 (Ch. 1952), aff'd, I2 N.J. 88, 95 A.2d 905 (1953), with In the Matter of Estate of Adler, supra. Professor Krasnowiecki argues, however, that the trustee's major duty is to cause the business to produce income. Therefore, if this goal, in the long run entails the reservation of funds from income, then accumulation should be judicially acceptable. Krasnowiecki, Existing Rules of Trust Administration: A Stranglehold on the Trustee-Controlled Business Enterprise, II: The Incorporated Business, 110 U. PA. L. Rev. 816, 824 (1962).
} 


\section{Expanding the Business}

To undertake and sustain the settlor's business is certainly consonant with the trustee's minimal duties. However, it may be concluded that merely sustaining the business is not sufficient to satisfy the purposes of the trust. In a business economy, the prospect of rapid obsolescence of machinery and methods, variations in consumer desires, and pressures of competition may compel the trustee to ensure his business a solid position in the economic community by taking advantage of opportunities to initiate industrial changes and expansion. Also, the fact that a trustee may be surcharged for too conservative an administration ${ }^{82}$ and that his compensation usually varies directly with the income from the trust ${ }^{83}$ may be incentives to progressive action.

At this critical stage, the trustee must squarely face the question whether trust concepts and judicial attitudes enable him to operate successfully as the supervisor of a business. Since any program of stabilization and expansion of a business may involve expenditures in such areas as research, advertising, and initiation of new techniques with the resultant need to acquire new and better assets, the trustee will have to contend with the rule as to improvements if his plans include substantial alteration of his existing physical plant and the rule as to investments if, in general, his plans call for the outlay of any substantial amount of money. ${ }^{84}$ Thus, these rules will control the extent to which the trustee is able to exercise his entrepreneurial talents.

\footnotetext{
${ }^{82}$ See Commercial Trust Co. v. Barnard, 27 N.J. 332, 142 A.2d 865 (1958).

${ }^{83}$ Some statutes, e.g., N.Y. SuRR. Cr. ACr $\$ \S 285-2$, 285-b, provide for compensation of trustees according to certain percentages of the principal and income of the trust received and paid over by the trustees. Otherwise, the normal rule is that the trustee is entitled to compensation reasonably related to the value of his services. E.g., Stevenson v. Moeller, 112 Conn. 491, 152 Atl. 889 (1931); Hayward v. Plant, 98 Conn. 374, 119 Atl. 341 (1923); Berry v. McCourt, 1 Ohio App. 2d 172, 204 N.E.2d 233 (1965).

When the trustee is operating a business and his compensation is fixed according to a percentage of the principal and income involved, he is entitled only to that percentage even though the carrying on of a business may involve more time-consuming and exacting activities for the trustee than are usually associated with trust administration. In re Larrabee, 98 N.J. Eq. 655, 130 Atl. 195 (1925); Matter of Rosenberg, 251 N.Y. 115, 167 N.E. 190 (1929); cf. In re Berri, 130 Misc. 527, 224 N.Y. Supp. 466 (Surr. Ct. 1927). See authorities cited note 31 supra for criticism of this rnle. Moreover, when a business is involved, the trustee is entitled to a percentage of the net, rather than gross, income of the trust. E.g., In re Larrabee, supra; Matter of Sidenberg, 204 App. Div. 255, 197 N.Y. Supp. 767 (1923).

84 There are indications that "improvement" and "investment" problems are not mutually exclusive. See notes 90-94 infra and accompanying text.
} 
In this connection, it is generally held that power to improve trust property must be explicitly granted in the trust instrument. ${ }^{85}$ As noted above, ${ }^{86}$ this rule is believed to be based upon the rights of legal life tenants and remaindermen. ${ }^{87}$ However, since the position of the trustee vis-à-vis the remainderman is not strictly analogous to that of the legal life tenant, in that a trustee with general managerial control of the administration of an active trust acts neither for himself nor for the sole benefit of the income, beneficiary, ${ }^{88}$ implied power to improve is sometimes found when the alterations are necessary to preserve the trust property or to make it productive. ${ }^{80}$ While judicial analysis in reliance upon such factors does not adequately distinguish "repairs" from "improvements," ${ }^{90}$ nevertheless, the cases in which issues of preservation and productivity do exist and power

${ }^{85}$ E.g., Russell v. Russell, 109 Conn. 187, 145 Atl. 648 (1929); Booth v. Bradford, 114 Iowa 562, 87 N.W. 685 (1901); Maynard v. Columbus, $150 \mathrm{Ky.} \mathrm{817,} \mathrm{150} \mathrm{S.W.} 1019$ (1912). See BOGERT $\$ 601$, at $370-71$, for a.catalogue of those items which have been held to constitute improvements.

${ }^{88}$ See note 72 supra and accompanying text.

${ }^{87}$ See Hartford Nat'l Bank \& Trust Co. v. The Parish of Trinity Church, 25 Conn. Supp. 23, 195 A.2d 566 (1963) (erecting commercial building on unproductive land held sanctioned by charitable trust, with reference to fact that no remainderman's interests thereby impaired); Smith v. Keteltas, 62 App. Div. 174, 170 N.Y. Supp. 1065 (1901) ("the interest of the remainderman is not be depleted or charged with improvements unless authority to that end can be derived from some compctent source").

At common law, a legal life tenant could not prejudice the capital value of the remainderman's interest by charging thereto the cost of altering the property. Nairn v. Marjoribanks, 3 Russ. 582, 38 Eng. Rep. 693 (Ch. 1827) (by implication). The reason is that any such act is the voluntary act of the life tenant, for which the remainderman should not be held responsible. Cf. Caldecott v. Brown, 2 Hare 144, 67 Eng. Rep. 60 (Cb. 1842). Thus, a trustee should have no greater power. See Estate of Cole, 102 Wis. 1, 9, 78 N.W. 402, 405 (1899).

88 See 2 PerRY, Trusts \& Trusters $\$ 477 b$, at 817 (7th ed. 1929); 3 Scott $\$ \$ 232-41$.

${ }^{80}$ In re Boyd, 231 Iowa 1325, 1332, 4 N.W.2d 387, 392 (1942) (dictum); Jordan v. Jordan, 192 Mass. 337, 343, 78 N.E. 459, 460 (1906) (trustees, in exercise of sound business judgment, might make extensive alterations so that income could be kept at a fixed standard or increased in amount); Spooner v. Dunlap, 87 N.H. 384, 180 At1. 256 (1935); In the Matter of Will of Ambrose, 12 App. Div. 2d 687, 207 N.Y.S.2d 930 (1960) (memorandum decision). But see Russell v. Russell, 109 Conn. 187, 145 Atl. 648 (1929).

In Russell, when trustees applied for judicial authority to rebuild a trust building burned in a fire, the court noted the strict rule that authority to improve must be explicitly granted in the trust instrument. Id. at 194-95, 145 Atl. at 652. The court did indicate that it would sanction a plan of improvements in the excrcise of its equitable power to allow deviation from the terms of the trust. Id. at 199-200, 145 Atl. at 652. However, the court warned that "it is the necessity of the situation which brings [the equitable power of deviation] . . . into operation, not the mere fact that thereby the estate may be administered in a way which will be more advantageous to its beneficiaries." Id. at 199, 145 Atl. at 652. Compare Jordan v. Jordan, supra.

${ }^{\circ 0}$ Indeed, when the physical acts involved are the same and the reasons for making the alterations are distinguishable, to call one class of alterations "repairs" and another "improvements" does not seem to serve any useful purpose. 
to alter is denied indicate that the actual test the courts apply is whether the expenditure will have an overall beneficial result for the trust. In Parry's Estate, ${ }^{91}$ where the settlor left assets including an unproductive beach hotel and the trustee expended substantial sums in rehabilitating and expanding the premises, the court explicitly viewed the transaction as an investment by the trustee and found that

[no] . . . careful man, dealing with his own property, knowing that no income had resulted to the estate from the running of this hotel, would have put a dollar of his own into its enlargement, much less would have put into it moneys of an estate of which he was trustee. ${ }^{92}$

Similarly, in the case of In re Miller, $_{9}^{93}$ the trustee of farm land which could not profitably be leased petitioned the court for permission to change the farm house to an inn and to construct a golf course. Noting that the land as it was could not produce a reasonable income, the court nevertheless found that to undertake the proposed changes in the hope of larger returns to the beneficiaries was to assume too great a risk. ${ }^{94}$ This view of the trustee's transactions as constituting an investment and the resultant application of investment rules may raise serious obstacles to a trustee's taking advantage of business opportunities to expand and consolidate his enterprise.

Generally speaking, two distinct rules governing the investment of trust funds developed concurrently in the United States. In 1830, the Massachusetts Supreme Judicial Court held, in Harvard College ข. Amory, ${ }^{95}$ that investments in corporate stock might properly be made since

all that can be required of a trustee to invest, is, that he shall conduct himself faithfully and exercise a sound discretion. $\mathrm{He}$ is to observe how men of prudence, discretion, and intelligence manage their own affairs, not in regard to speculation, but in regard to the permanent disposition of their funds, considering the probable income, as well as the probable safety of the capital to be invested. ${ }^{96}$

\footnotetext{
${ }^{01} 244$ Pa. 93, 90 Atl. 443 (1914).

${ }^{92} \mathrm{Id}$. at 98, 90 Atl. at 445 .

${ }^{08} 62$ N.J. Eq. 764, 49 Atl. 149 (1901).

or Id. at 767, 4 Atl. at 150 .

os 26 Mass. (9 Pick.) 446 (1830).

${ }^{\circ B}$ Id. at 461 .
} 
The Amory rule, known as the "Massachusetts Rule of Trust Investments" or the "Prudent Man Rule," 97 was ostensibly followed by the New York Court of Appeals in King v. Talbot ${ }^{98}$ but with a narrow interpretation of "prudence." The Talbot court, notwithstanding that prudent men do, in fact, invest in shares of corporate enterprises, reasoned that in such a situation the safety and control of the trust fund was surrendered to the managers of the business and the hazards of trade-a circumstance which in the relation of trust could not be countenanced.99 The court indicated that funds loaned upon bonds, mortgages, and other 'evidences of debt were the only proper investments which could be made by trustees.100 Undoubtedly, the primary consideration in Talbot was to insure the preservation of the funds for the remainderman.101 The upshot of the decision was adherence to the proposition that the role of the trustee was essentially conservatorial, ${ }^{102}$ the creation of a "circular" standard to which trustees were to conform their investments,

${ }^{97}$ See Shattuck, The Massachusetts Rule of Trust Investments, 82 TRUSTs \& EsTATES 23 (1946).

${ }^{98} 40$ N.Y. 76, 85-86 (1869).

${ }^{00} \mathrm{Id}$. at 88-89.

${ }^{100} \mathrm{Id}$. at 89 . Compare the early English rule, limiting proper trustee investments to government securities and first mortages. See 3 Scort $\$ 227.4$, at 1667 .

The Amory court directly controverted the proposition that certain types of investments could be classified as safer than others. 26 Mass. (9 Pick.) at 461.

${ }^{101}$ Several explanations have been advanced in support of the court's concern. First, the early theory and practice of trusts involved the settlor's placing a valuable "thing" in the hands of his trustee, which was to be preserved and eventually to be handed over to the remainderman, who was entitled to exactly that which had been originally given to the trustee. See Shattuck, New Theory of Trust Management, 84 TRusts \& EsTates 185, 186 (1947). The Industrial Revolution was accompanied by a change in the form of wealth, when intangibles such as stocks, bonds and currency became the primary indications thereof. The "thing" or "res" theory carried through, however, with the consequent recognition of the trustee's primary duty being to hand over the same value to the remainderman. Shattuck, supra at 188.

It has also been suggested that the conservatorial function of trusts is explainable on the grounds that, at the time settlors consider creating a trust, they are no longer the aggressive accumulators of wealth, but rather are mature consolidators, intent upon protecting that which they have accumulated. See Torrance, Legal Background, Trends and Recent Developments in the Investment of Trust Funds, 17 LAw \& ConTEMp. Pros. 128, 136-37 (1952).

102 See note 101 supra.

${ }_{208}$ "[T] $[$ he external standard of 'such care and skill as a man of ordinary prudence would exercise in dealing with his own property' is not the standard he would use in dealing with his own property if he had only himself to consider .... In other words he must take no risks which would not be taken by an ordinarily prudent man who is trustee of another person's property.

"The next observation to be made is that the primary object to be attained by a trustee in the matter of investing the funds confided to his control is their safety." 
and a number of statutes strictly delimiting the area of proper trustee investments and generally excluding investments in corporate stock. ${ }^{104}$

The view of the trustee's role as a conserver can be contrasted with the role of the ordinary businessman, a creator of wealth, whose financial manipulations are generally fraught with more substantial risks than are those of a conservative investor. ${ }^{105}$ In light of the traditional presumption that investments in business are inherently imprudent, ${ }^{108}$ the "trustee-entrepreneur" seems almost a contradiction in terms, since any expenditures to enlarge a business may be termed an investment in the business. ${ }^{107}$ This unfavorable judicial attitude first appears in the hesitancy. with which courts permit a trustee to undertake a settlor's business. ${ }^{108}$ The crucial question here, of course, is not how liberal courts should be in permitting a trustee to undertake a business, but rather what degree of freedom they should allow him once he has begun operating it. There are several factors which tend to the conclusion that investment factors should not stifle a trustee-businessman's attempt to keep his business abreast of the market.

First, because of increasing controls on the present economy, many of the elements of a laissez-faire economy, which made business investments especially hazardous in the first place, ${ }^{109}$ have been

In the Matter of Estate of Cook, 20 Del. Ch. 123, 126-27, 171 Atl. 730, 731 (Ch. 1934). (Emphasis added.) See Wilmington Trust Co. v. Coulter, 41 Del. Ch. 548, 559-61, 200 A.2d 441, 447-48 (Sup. Ct. 1964).

${ }^{204}$ Apparently to remedy the uncertainty which the "Massachusetts prudent man rule" engendered among trustees, at one time at least three-fourths of the American jurisdictions adopted "legal lists" of proper trustee investments. Legislation, 49 HARv. L. REv. 821 (1936) (containing a list and discussion of relevant statutes). Between 1830 and 1937, only six states adhered to the Massachusetts rule. Torrance, supra note 101 , at 138 .

${ }^{100}$ Comparison is often made between "speculation," a "businessman's risk" and a proper trustee investment: “A businessman's risk lies between the area of speculation and the area of trust investment. The characteristics of the businessman's risk often are (a) that the enterprise is not widely known to investors or (b) that the participation is selling on a yield basis which... is greater than the current rate or (c) the activities of the enterprise in question are of a wasting nature or are novel or are relatively hazardous." Shattuck, The Massachusetts Rule of Trust Investments, 82 TRusts \& Estates 23, 39 n.100 (1946).

${ }^{208}$ See, e.g., Clark v. Clark, 167 Ga. 1, 144 S.E. 787 (1928); Brown v. Brown, 72 N.J. Eq. 667, 65 Atl. 739 (1907); King v. Talbot, 40 N.Y. 76 (1869); Taylor's Estate, 277 Pa. 518, 121 Atl. 310 (1923); Hamphill's Appeal, 18 Pa. 303 (1852); Legislation, 49 HARV.

L. REv. 821 (1936) (statutes); Comment, 49 Yale L.J. 891 (1940).

107 See notes 91-94 supra and accompanying text.

${ }^{208}$ See note 14 supra and accompanying text.

${ }^{100}$ See Torrance, Fifty Years of Trust Investments, 93 Trusts \& EsTATES 250-52 
eliminated. This relative safety is reflected in the increasing replacement of "legal lists" of proper trustee investments with the "prudent man" rule. ${ }^{110}$ Although now proper investments under this rule generally must be in businesses that have a history of financial stability in a firmly entrenched commercial field, ${ }^{111}$ the "prudent man" revolution at least indicates a basic change in the once prevailing attitude toward business.

Second, the tenor of modern trust instruments, with liberal provisions in favor of income beneficiaries, indicates that settlors do not conceive the function of trusts to be rigidly conservational. ${ }^{112}$ To the contrary, well-drawn trust instruments now manifest a desire that trustees exercise more aggressive administration to build up, rather than merely conserve, income and principal. Since the professed aim of the courts is to find and follow the intent of the settlor, perhaps there are grounds for reassessing the justification for holding the trmstee to the standard of the prudent conserver.

Third, and most important, is the apparent judicial recognition, in two fairly recent cases, that utilizing trust funds to aid in the authorized continuation of a settlor's business is not properly characterized as an "investment," but rather as an outlay of funds inherently connected with the concept of continuing a business. ${ }^{113}$

(1952). "Perhaps it is too often forgotten that those were the days of such flamboyant operators as Jay Gould, Jim Fisk, and Daniel Drew; in fact [King of Talbot] . . . came in the spring of the same year as the famous "Black Friday" engineered by Gould and Fisk. Small wonder, that a court would frown upon the use by trustees of a form of investment which could so easily become a plaything for speculators . . . " Id. at 250 .

${ }^{110}$ Since 1987, "there has been a virtual parade toward the greater freedom of the Massachusetts rule." Torrance, Legal Background, Trends, and Recent Developments in the Investment of Trust Funds, 17 LAw \& Contemp. Prob. 128, 138 (1952). At latest count, only five states do not adhere to some form of the "prudent man" standard. Comment, 15 ALA. L. REv. 79, 90 (1962).

Apart from the recognition that investments in corporate stock are in fact prudent, other reasons for the change from legal lists to the "prudent man" rule include the realization after the Great Depression that no one type of investment can be said to be any safer than any other and the reaction to the restrictions which the "legal list" philosophy place on a trustee when circumstances, such as inflation, warrant a diversification of investments. Stevenson, Why the Prudent Man?, 7 VAND. L. REv. 74, 77-79 (1958).

111 See $\$$ Scotr $\$ 227.11$, at 1690 .

112 Shattuck, The Trustee's Duty to Invest, 86 Trusts \& EsTaTEs 119 (1948); Stevenson, supra note 110 , at $77-78$.

112 It is interesting to note that the concept of a trustee's engaging in business has been accepted by a court in a somewhat different context. In the Matter of Luckenbach, 188 Misc. 265, 42 N.Y.S.2d 791 (Surr. Ct. 1943), appeal dismissed mem., 267 App. Div. 998, 48 N.Y.S.2d 807 (1944), aff'd mem., 269 App. Div. 948, 58 N.Y.S.2d 330 (1945), trustees were empowered to carry on testator's tugboat business for as long as it might 
Thus, in Conant $v$. Lansden, ${ }^{114}$ the testator, owner of a majority share in a mercantile corporation, empowered his trustees to

manage, use and conduct all of [his] . . property, business and affairs in such a manner as will in their judgment, yield and the best and safest income, interest and profits .... ${ }^{115}$

When the business encountered financial difficulties, the trustees lent trust funds to the store on an unsecured demand note. The store ultimately failed and full satisfaction of the loan was not realized. The lower court found that since the store was in an uncertain financial condition at the time of the loan, the investment was hazardous and therefore unsuitable for trust funds. ${ }^{116}$ The trustees were surcharged for the loss. Reversing the decision, the Illinois Supreme Court found that though the loans were an "investment" they were also a "means of preserving the Tamms Mercantile Company"117 and that the terms of the will authorized the trustees to continue the business.

Similarly, in Holmes $v$. Hrobon, ${ }^{118}$ the testator empowered his trustee to

conduct and carry on the laundry business ... and to do all things necessary or proper in the usual course of said business ... as long as the same may be profitable..$^{119}$

Over a five-year period, the trustee acquired five competing firms at a cost of 103,900 dollars. The beneficiary objected to these expenditures and sought to hold the trustee accountable for them. The

remain profitable. In the course of operations, the trustees expanded the business until ultimately they were engaged in intercoastal traffic with ocean-going steamers. In an accounting, after the business had been sold, the remaindermen claimed the value of the good will of the business as properly theirs. The trustees resisted with the allegation that the testator's business had been "discontinued" since the business was being conducted on a much grander scale than that in which the testator was engaged. In holding for the remaiudermen, the court found that the changes wrought by the trustees were incideut to the normal operation of the shipping business, that no business can remain static, and that therefore, the trustee's administration was in compliance with the testator's direction that the business be continued. 188 Misc. at 275, 42 N.Y.S.2d at 798.

114409 Ill. 149, 98 N.E.2d 773 (1951), affirming in part, reversing in part 341 Ill. App. 488, 94 N.E.2d 594 (1950).

135341 Ill. App. at 497,94 N.E.2d at 598.

110 Id. at 498,94 N.E.2d at 599.

117409 ril. at 155,98 N.E.2d at 777 .

${ }^{118} 158$ Ohio St. 508, 110 N.E.2d 574 (1953), affirming in part, reversing in part 93 Ohio App. 1, 103 N.E.2d 845 (1951).

${ }^{139} 158$ Ohio St. at $515-17,110$ N.E.2d at 580. 
lower court held that the trustee could not purchase new businesses without express authorization from the settlor; that the power

to do "all things necessary" means to do all things necessary as a trustee and not as sole proprietor. The direction ... to continue the business "as long as the same may be profitable" does not authorize the trustee to do everything necessary to make the business profitable as he would do if it were operated by him as sole proprietor. ${ }^{120}$

The Ohio Supreme Court reversed the decision on this point, finding the powers of the trustee sufficiently broad to authorize all expenditures necessary in the exercise of sound business judgment to operate, maintain, and expand the business. ${ }^{121}$

The significance of Conant and Holmes is highlighted by the fact that the lower court decisions exemplified traditional means of treating trustee action. In Conant, the lower court abstracted the trustee's loan from the realities of the transaction and viewed it as an independent investment, applying the investment standard of the "prudent man" rule. In Holmes, the distinction between the trustee as prudent businessman and the trustee as prudent investor resulted in the express denial of resort to some of the techniques of effective business management.

The facility with which the supreme courts in Conant and Holmes side-stepped the alternative analyses presented by the lower courts does not indicate a revolution in the theory and application of trust law; rather, the positions adopted demonstrate a realization that the essential factor is that the trustee is operating a business. Thus, while the trustee-entrepreneur must always conduct himself as a prudent man would, the fact that he is engaged in business operations and must of necessity take the risks incident to such activity provides the major factor in light of which prudence is to be judged.

\section{ConcLusion}

While courts are reluctant to allow a trustee to become involved in a business, the central concept of trusteeship-reasonable prudence under the circumstances-should allow a trustee, once he has undertaken a business at the direction of a settlor, to manage it efficiently and successfully according to common business principles. The full

22093 Ohio App. at 32, 103 N.E.2d at 864.

121158 Ohio St. at 527, 110 N.E.2d at 585. 
potential of this concept has been realized only to a limited extent. Thus, with regard to the allocation of responsibility for details of business management, the trustee may adopt a procedure consistent with the practices dictated by prudent business principles. ${ }^{122}$ In a like manner, as the operation of the business progresses, the trustee should be able to manipulate his holding as would any prudent businessman, taking the steps necessary to adjust to the forces of the market place. Unfortunately, it is presently unclear whether the trustee may proceed only if a cautious investor would invest funds in the business. It is submitted that if there exists a general policy to discourage the leaving of businesses in trust, to effectuate this policy by restrictive rules applied to the trustee after he has undertaken to operate a business is productive of unnecessary economic waste in the form of unsuccessful enterprises. Such waste can be easily prevented simply by prohibiting the business-in-trust form or, on the other hand, by granting the trustee the leeway available under the rule of reasonable prudence.

The present undeveloped and illiberal state of affairs in this area of the law is probably attributable to the fact that the relative dearth of litigation involving trustee-managed businesses has not given the courts sufficient opportunity to view the factors involved in depth. As the incidence of business held in trust increases, with, presumably, further judicial consideration of such holdings, it is hoped that rules embodying modern commercial exigencies will evolve.

\footnotetext{
${ }^{122}$ See notes $36-38,46$ supra and accompanying text.
} 